2. Brimson, J. A. Driving Value Using Activity-Based Budgeting [Text] / J. A. Brimson, J. Antos. - John Wiley \& Sons, Inc. 1998. - 288 p.

3. Mihaila, S. The Importance of Budgeting for Strategy Implementation [Text] / S. Mihaila, O. Ghedrovici, G. Badicu / European Journal of Accounting, Finance and Businessg. 2015. - Vol. 3. No. 2. - P. 57-69.

4. Ageeva, T. Yu. Rol' biudzhetirovaniia v sisteme upravleniia prepriiatiem [Electronic resource] / T. Yu. Ageeva, S. L. Ulina // Sibirskii federal'nyi universitet. - Available at: \www/URL: http://www.sworld.com.ua/simpoz2/122.pdf

5. Anshin, V. N. Biudzhetirovanie v kompanii: Sovremennye tehnologii [Text] / V. N. Anshin. - Moscow: Delo, 2010. - 288 p.

6. Voinarenko, M. P. Problemy reformuvannia i shliakhy tranzytsii bukhhalterskoho obliku do Mizhnarodnykh standartiv [Text] / M. P. Voinarenko // Visnyk Tekhnolohichnoho universytetu Podillia. - 2000. - Vol. 5, Part. 2. - P. 9-13.

7. Nazarova, V. Budgeting Systems in the Strategic Management Accounting [Text] / V. Nazarova, M. Shtiller, I. Selezneva, O. Kohut, G. Seitkhamzina // Indian Journal of Science and Technology. - 2016. - Vol. 9, No. 5. - P. 1-11

8. Laporšek, S Theoretical views on the firm's objectives. Which one to choose? [Electronic resource] / S. Laporšek, I. Stubelj, P. Dolenc. - 2012. - P. 645-657. - Available at: \www/URL: http://www.antim.rs/Fajlovi/ANTiM-2012-Vol.2.pdf

9. Kolesnik, M. K. Sbalansirovannaia sistema pokazatelei kak sposobpovysheniia effektivnosti upravleniia deiatel'nost'iu predpriiatiia [Text] / M. K. Kolesnik, G. V. Rubaha // Ekonomika, planirovanie i upravlenie v lesoproizvodstvennom komplekse. 2008. - No. 18.5. - P. 225-230.

10. Noskova, N. Yu. Protsessno-orentirovannoe biudzhetirovanie kak instrument dostizheniia strategicheskih tselei predpriiatiia [Electronic resource] / N. Yu. Noskova // Izvestiia RFEI. 2016. - No. 1. - Available at: \www/URL: http://science.rfei.ru/ $\mathrm{ru} / 2016 / 1 / 144 . \mathrm{html}$

11. Soroka, I. The introduction of a budgeting system in the russian companies on the experience of leading foreign companies [Text] / I. Soroka // Transportnoe delo Rossii. - 2011. No. 6. - P. 176-177.
12. Polishchuk, S. Formuvannia intehrovanoi systemy biudzhetuvannia mashynobudivnykh pidpryiemstv [Text] / S. Polishchuk // Sotsialno-ekonomichni problemy i derzhava. - 2013. Vol. 2 (9). - P. 240-248.

13. Chybisov, Yu. V. Pryznachennia ta sutnist systemy biudzhetnoho upravlinnia [Text] / Yu. V. Chybisov // Problemy teorii ta metodolohii bukhhalterskoho obliku, kontroliu i analizu. Seriia: Bukhhalterskyi oblik, kontrol i analiz. - 2005. - Vol. 2. - P. 192-202.

14. Shaikan, A. V. Accounting with the purpose of strategic management as the instrument of domestic enterprises integration into the world economy [Electronic resource] / A. V. Shaikan // The Journal of Zhytomyr State Technological University. Series: Economics. - 2009. - Vol. 49, No. 3. - Available at: \www/ URL: http://ven.ztu.edu.ua/article/viewFile/91201/89257

\section{ИССЛЕДОВАНИЕ МЕХАНИЗМА ВЗАИМОСВЯЗИ УЧЕТА И БЮДЖЕТИРОВАНИЯ В СИСТЕМЕ УПРАВЛЕНИЯ ДЕЯТЕЛЬНОСТЬЮ ПРЕДПРИЯТИЙ: СТРАТЕГИЧЕСКИЙ АСПЕКТ}

Проанализированы результаты последних исследований ученых и определены принципы, значение бюджетирования, его взаимосвязь с учетом в системе управления деятельностью предприятий. Идентифицировано влияние различных видов учета и возможности интеграции с составляющими системы управления для достижения стратегических целей. Определена последовательность формирования отчетности по центрам ответственности и информационная связь между бюджетами целевой себестоимостью и нормативами расходов. Сформулированы преимущества механизмов взаимосвязи бюджетирования с бухгалтерским учетом.

ключевые слова: система стратегического управления, учетно-аналитическое обеспечение, взаимосвязь бюджетирования с бухгалтерским учетом.

Shevtsiv Lyba, PhD, Associate Professor, Department of Accounting and Auditing, Ivan Franko National University of Lviv, Ukraine, e-mail: Shevtsivlyba@gmail.com, ORCID: http://orcid.org/00000003-4960-3198

\section{Liakhovych H.}

\title{
CLASSIFICATION OF ACCOUNTING OUTSOURCING: COMPLIANCE WITH MODERN DEVELOPMENT TRENDS
}

Проведено аналіз існуючих на съогоднішній день класифікацій бухгалтерського аутсорсингу. Очінено визначені науковиями класифікащійні ознаки на відповідність потребам в забезпеченні ефективності бухгалтерського аутсорсингу. Запропоновано здійснювати його класифікацію за такими ознаками, які представлено у трьох групах: залежно від послуг, які надаються; залежно від суб'єктів господарювання та залежно від вимог до організації аутсорсингу.

Ключові слова: бухгалтерський аутсорсинг, організащія бухгалтерського обліку, класифікація бухгалтерського аутсорсингу.

\section{Introduction}

The difficult economic situation in Ukraine forces enterprises to seek and implement effective measures to optimize their expenses. To achieve this aim, enterprises are increasingly turning to business process outsourcing, in particular to accounting outsourcing. However, the effectiveness of its implementation depends on many factors, one of the main is properly organized the process of transition to outsourcing. And this, in turn, requires consideration of the features of its implementation for each species.

There is no model of accounting outsourcing, which would be universal and suitable for all business entities. The final decision on the choice of a specific type of accounting outsourcing should be based on an analysis of all its varieties and taking into account those features that are appropriate for a particular enterprise. The above confirms the relevance of the study of accounting 
outsourcing classifications in order to determine its types that affect the organization process.

\section{The object of research and its technological audit}

The object of research is accounting outsourcing.

In order to ensure the organization of the accounting outsourcing process, the types of accounting outsourcing are investigated in this research. The concept of accounting outsourcing, being one of the main world trends in the development of the organization of accounting, is becoming increasingly common in Ukrainian business practice. However, despite this, the issue of classification of accounting outsourcing remains open, especially in the context of identifying species that should be taken into account when choosing the form of accounting organization.

\section{The aim and objectives of research}

The aim of research is substantiation of the classification characteristics and determination of the types of accounting outsourcing, which have a decisive impact on the organization of accounting.

To achieve this aim, the following tasks are defined:

1. To conduct an analysis of the currently existing types of accounting outsourcing.

2. To evaluate options for providing accounting outsourcing services.

3. To improve the classification of accounting outsourcing by identifying characteristics, having a decisive influence on the organization of accounting.

\section{Research of existing solutions of the problem}

Theoretical bases of accounting outsourcing are revealed in the works of many scientists. In most works, considering the problems of organizing accounting outsourcing, scientists pay attention to specific types of it. Characteristics and features of implementation lead to offshoring [1-8] and co-sourcing [9, 10]. Disclosure of types of outsourcing for these and other models of the provision of services is carried out in [11].

However, there is no unanimity among scientists regarding the relationship between these models of providing services by outsourcing. Also, works [10, 12, 13] consider types of outsourcing without specifying classification characteristics. All this confirms that not all improvements have met the requirements for the construction of classifications. Comprehensive research on the types of accounting outsourcing implemented in the work in terms of classification:

- for management needs [14];

- in terms of customer needs [15-17].

Given the foregoing, the issues of researching the types of accounting outsourcing for the needs of the organization are important.

\section{Methods of research}

To solve the problems, the following methods are used: analysis and synthesis, logical generalization, analogies, comparative comparison, graphical method.

\section{Research results}

Normative legal acts classification of accounting outsourcing, as well as the interpretation of this process, is not approved. This is one of the reasons for the lack of unity in the definition of signs and types of accounting outsourcing in scientific works and the desire of researchers to develop their own classification, which would correspond to the current economic trends.

In the economic literature most often distinguish the following classification characteristics:

- sphere (scale and form) of application;

- customer (tax status of the customer, etc.);

- orientation of services to meet the needs of the

client (the direction of providing services, the content

of services, etc.);

- types and forms of responsibility;

- interaction with external bodies;

- types of reporting.

Considering approaches to the classification of accounting outsourcing, it can be noted that the vast majority of scientists [18-21] point to such types of outsourcing as full and partial. Full outsourcing is understood as the transfer of all accounting functions to the outsourcer by the enterprise, and a partial one provides for the outsourcing of certain non-core functions, in particular the preparation and submission of reports, the maintenance of personnel records.

In addition, the authors [18, 19] separate advanced outsourcing, that is, the transfer of certain functions by the enterprise, subject to control over their implementation. The author in [20] considers it expedient to additionally allocate two more models of accounting outsourcing:

- external controller (the outsourcer checks the accounting documentation, analyzes the work of the enterprise and gives an opinion on how to improve the activity);

- subscriber service (outsourcer acts as a consultant, informs the customer about innovations and other issues).

Let's agree with the position of the scientist, allowed mixed options for cooperation between the customer and the contractor. An example can be the maintenance of outsourcing personnel records and the simultaneous control over the correctness of accrual and the payment of wages by a regular accountant. Quite often outsourcers simultaneously provide accounting and consulting services in terms of organizational issues (selling land property, equipment, the procedure for export-import operations, etc.).

The scientist [14] cites his own classification of outsourcing services, built to manage the process of accounting outsourcing of organizations, in terms of accounting, management analysis, control and planning. For these purposes, the following criteria are defined:

- subject and direction of outsourcing;

- methods used to provide outsourcing services;

- labor intensity; terms and frequency of outsourcing services;

- place and method of providing outsourcing services;

- characteristics of served customers;

- type of outsourcing organization;

- forms of outsourcing services.

In addition, the author notes that the classification of accounting outsourcing services should be based on 
the criterion of satisfying the client's need, according to which services can be grouped as follows:

- direct services (actually accounting outsourcing) meet customer needs;

- indirect (accompanying) services (consulting services, selection of a package of normative documents and (or) amendments and additions to them) - facilitate the provision of accounting outsourcing;

- additional services (services for preparation and submission of financial statements and other documents to the relevant authorities, training of the client's personnel, publication of special literature for accountants) facilitate the receipt of additional income or reduce costs when providing direct services.

The types of services should be considered when building the classification, but their excessive detailing will only complicate the process of outsourcing. Although there are opposite points of view. Thus, scientists [13] believe that in order to improve the efficiency of quality management and quality of management of the process of obtaining services, accounting outsourcing needs to be classified in more detail:

- processing and management of business operations in 1C (settlement services with suppliers, settlement and cash management services, payroll services);

- preparation and submission of reports (services for the formation of accounting reporting filing);

- analysis and tracking of debts on counterparts;

- analysis of commodity balances in warehouses;

- analysis of the accounting of the assets of the enterprise (fixed assets, other non-negotiable tangible assets, intangible assets, etc.);

- property management services;

- consultations on accounting and tax accounting (oral);

- courier delivery from/to the client documents;

- processing of operations of foreign economic activity;

- registration of inventory results;

- checking the correctness of the initial documentation;

- passing of inspections for the reporting period;

- sorting and systematization of documents;

- compilation of production calculations;

- write-off of construction materials;

- introduction of changes in previous periods with submission of reports;

- departure of the specialist to the customer;

- extract of the primary documentation;

- consultations on accounting and tax accounting

(written);

- training and instructing staff on accounting matters;

- optimization of accounting documents;

- preparation of documents for VAT refund;

- preparation of documents for submission to the bank for credit registration;

- forecast of tax liabilities;

- passing of checks for previous periods;

- submission of reports in electronic form;

- preparation of internal financial statements;

- drafting an order on the accounting policy of the enterprise;

- formation of payment orders in Internet banking, storage of customer documentation in the boxes; tax planning, development of schemes and support.

The considered classification to be the most complete in terms of differentiating the services provided by out- sourcing companies. However, this classification is focused only on the service provider and its capabilities and does not take into account other important components that concern the customer, the organization of accounting and the order of cooperation and those that have already been considered in the writings of other authors.

Analyzing the approaches to the classification of accounting outsourcing by different scientists, the types of accounting outsourcing into three main categories are grouped: depending on the provided services; depending on the subjects of management and depending on the requirements for its organization.

The first category includes types of accounting outsourcing, systematized by the content of services. These include:

- direct services, that is, services that are directly related to the management and organization of the customer's accounting (development of the accounting system, restoration of accounting, record keeping);

- related services - services arising in the process of cooperation between the parties to the relationship (consulting services and support (representing the interests of the customer in state instances);

- additional services are services that are not related to the main and related ones, and which can be included in the scope of the contractor's activity (increase of the professional knowledge of the customer's accounting personnel).

Depending on business entities, accounting outsourcing can be divided by types of business entities, by tax status and by location of business entities. Depending on the type of enterprise, accounting outsourcing is distinguished for individuals (individual entrepreneurs) and for legal entities (private enterprises, companies, foreign enterprises). Depending on the tax status, the customer is recorded on the general and simplified taxation systems. Domestic, national and international accounting outsourcing is identified at the location of economic entities. With internal outsourcing, the customer and the executor are located in the territory of one country, however, they can be residents of both one and different countries. Subjects of national accounting outsourcing are residents of only one country. The use of this type of accounting outsourcing deprives the customer of the possible language, cultural and other barriers. In the case where the offices of the customer and the executor are located in different countries and the subjects of accounting outsourcing are residents of different countries, international accounting outsourcing arises.

In order to justify the specifics of the organization of accounting, let's consider it necessary to use those classification characteristics, certain types of which directly affect this process (Table 1 ).

In the presented classification, types of outsourcing that take into account modern trends of development are highlighted, and which are the most popular. In [12], individual species are represented under different names. So, in the order of cooperation (the way services are provided), centralized or local outsourcing is singled out. In the first case, services are provided at the main office of the outsourcer, in particular, in the accounting department. Services provided at the local level are performed at the central office of the enterprise, transfers resources, tasks or processes, activities. 
Classification of accounting outsourcing, taking into account the requirements for its organization*

\begin{tabular}{|c|c|c|c|}
\hline No. & Attribute & Type & Characteristic \\
\hline \multirow{2}{*}{1} & \multirow{2}{*}{ Time period } & Long-term nature & $\begin{array}{l}\text { Type of outsourcing, according to which the implementation of the delegated business process is provided for } \\
\text { a long period (more than a year) }\end{array}$ \\
\hline & & Temporary nature & $\begin{array}{l}\text { Type of outsourcing, which provides for the performance of work in a clearly defined time and without } \\
\text { prospects for their recurrence }\end{array}$ \\
\hline \multirow{2}{*}{2} & \multirow{2}{*}{$\begin{array}{l}\text { Cooperation } \\
\text { order }\end{array}$} & Remote & $\begin{array}{l}\text { Type of outsourcing that involves the use of information and computer technologies without personal contact } \\
\text { between the customer and outsourcer }\end{array}$ \\
\hline & & $\begin{array}{l}\text { Stationary (non- } \\
\text { distance) }\end{array}$ & $\begin{array}{l}\text { Type of outsourcing that is characterized by a constant contact between the customer and the outsourcer, the } \\
\text { transmission of data both personally and using information and computer technology }\end{array}$ \\
\hline \multirow{2}{*}{3} & \multirow{2}{*}{$\begin{array}{l}\text { Implementation } \\
\text { mechanism }\end{array}$} & Cross & Type of outsourcing that provides for performing the assigned functions of outsourcing outsourcers \\
\hline & & Direct & Type of outsourcing that is performed exclusively by outsourcers without attracting his side to additional subjects \\
\hline \multirow{2}{*}{4} & \multirow{2}{*}{ List of works } & Full & Type of outsourcing, which provides for the transfer of all work on the organization and accounting \\
\hline & & Partial & Type of outsourcing, which provides for the transfer of only individual work on the organization and accounting \\
\hline \multirow{4}{*}{5} & \multirow{4}{*}{$\begin{array}{l}\text { Models of } \\
\text { accounting ser- } \\
\text { vices provision }\end{array}$} & Classic outsourcing & Type of outsourcing, which provides for the provision of services by a third party \\
\hline & & Insourcing & $\begin{array}{l}\text { Type of outsourcing, which provides for the creation of its own autonomous structural units (companies) that } \\
\text { provide specialized services, both to business units and external counterparties }\end{array}$ \\
\hline & & Co-sourcing & $\begin{array}{l}\text { Type of outsourcing that provides for the separation of accounting functions between the internal personnel } \\
\text { of the enterprise-customer, and external resources, that is, outsourcers }\end{array}$ \\
\hline & & Offshoring & $\begin{array}{l}\text { Type of outsourcing that involves the transfer of jobs requires a high level of skill, from countries with high } \\
\text { labor costs to countries with lower costs. This led to the development of service centers for accounting ser- } \\
\text { vices mainly in India, Malaysia and a number of European countries (Hungary, Czech Republic and Poland) }\end{array}$ \\
\hline
\end{tabular}

Note: ${ }^{*}$ is built on the basis of data [22].

The advantage given in Table 1 classification is the availability of detailed characteristics of each planned species, which greatly facilitates its perception and research. It can also be said about the all-encompassing nature of the above classification (takes into account all important classification characteristics (time period, cooperation procedure, implementation mechanism, list of works, models for providing accounting services)
The proposed classification largely depends on the specifics of the formation of the relationship between the parties to the contract - the customer and the executor (Fig. 1).

Consideration of the dependence of the types of accounting outsourcing with the process of forming relationships between the parties to the contract shows that the contractor provides services in accordance with the form and taking into account the tax status to the customer.

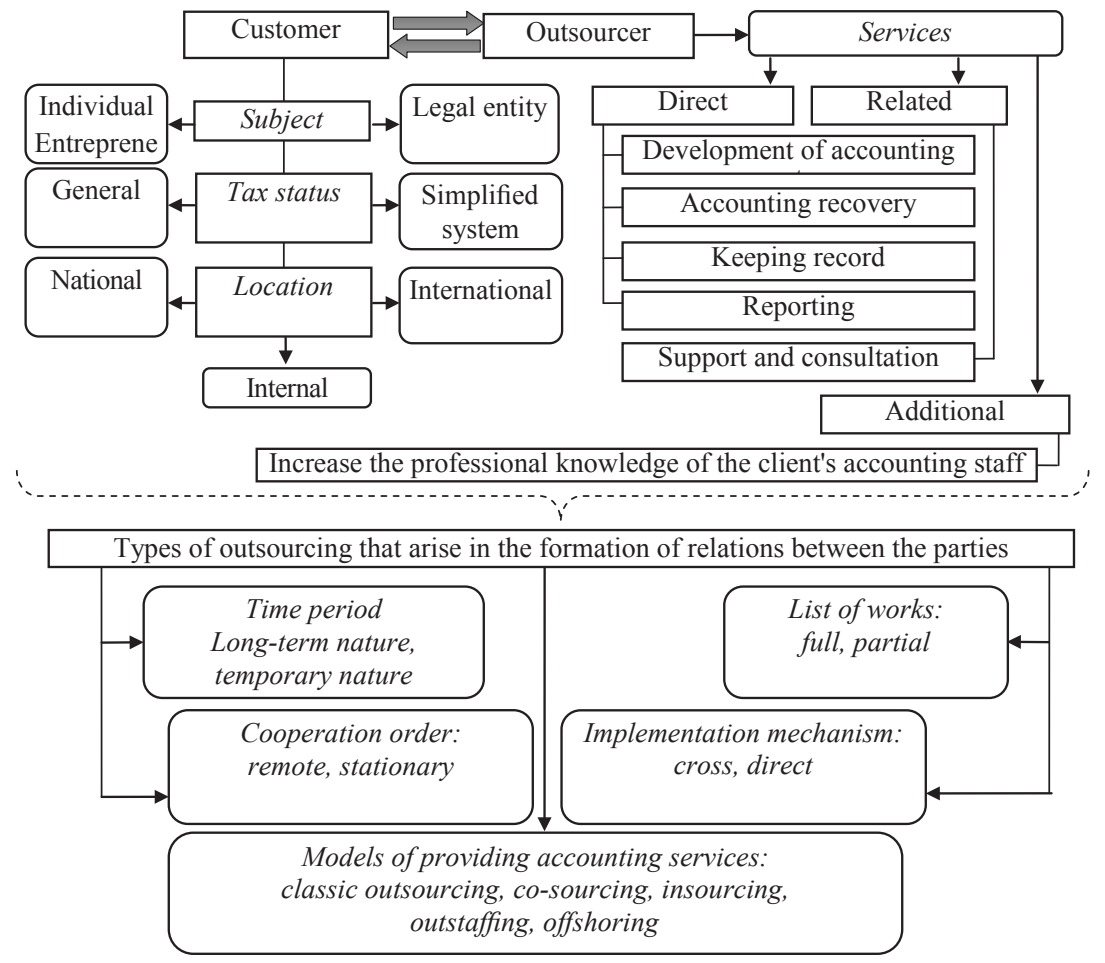

Fig. 1. Connection of the proposed types of accounting outsourcing with the process of forming relationships between the parties to the contract 


\section{SWOT analysis of research results}

Strengths. The strength of the research is the analysis of the views of scientists in terms of the proposals made on the types of accounting outsourcing and identification of those characteristics that have a decisive influence on the organization of the transition to outsourcing, to establish the relationship between the parties to the transaction.

Weaknesses. The weak side is the difficulty in adapting the approaches of foreign scientists to the realities of Ukraine, due to the lack of a single categorical apparatus in the field of outsourcing, as well as uncertainty and instability in legislation.

Opportunities. Opportunities for further research are the improved organization of the transition to accounting outsourcing.

Threats. Threats to the results of the conducted research are changes in regulatory legal acts that will impose restrictions on the implementation of a particular type of accounting outsourcing.

\section{Conclusions}

1. Based on the results of the analysis of the positions of scientists, it is established that there is no systematicity in the disclosure of classification characteristics, according to which types of accounting outsourcing are delimited in literary sources. Despite the rather high level of research on this issue, there is no clear unity in the allocation of relevant types of accounting outsourcing.

2. In the classical form, services for accounting services outsourcing are rather rare. As a rule, outsourcers and enterprises-customers resort to combined options, which makes it necessary to take into account many criteria when developing the classification of accounting outsourcing. Only if all factors are taken into account is it possible to effectively organize the transition to outsourcing.

3. The types of accounting outsourcing are systematized and presented in the context of three groups of characteristics:

- depending on the provided services;

- depending on the subjects of management (types of business entities, tax status and location of business entities);

- depending on the requirements for outsourcing organization (time period, cooperation procedure, implementation mechanism, list of works, models for providing accounting services)

It is confirmed that the proposed classification largely depends on the specifics of the formation of the relationship between the parties to the contract - the customer and the contractor.

\section{References}

1. Nicholson, B. Managing attrition in offshore finance and accounting outsourcing [Text] / B. Nicholson, A. Aman // Strategic Outsourcing: An International Journal. - 2012. - Vol. 5, No. 3. - P. 232-247. doi:10.1108/17538291211291765

2. Szymaniak, A. Globalizacja usług. Outsourcing, offshoring i shared services centers [Text] / ed. by A. Szymaniak. - Warszawa: Oficyna Wydawnicza ŁOŚGRAF, 2006. - 432 p.

3. Marcinkowska, E. Outsourcing i offshoring procesu rachunkowości - modele dostawy usługi [Text] / E. Marcinkowska // Prace Naukowe Uniwersytetu Ekonomicznego we Wrocławiu. 2015. - No. 399. - P. 333-342. doi:10.15611/pn.2015.399.32
4. Marcinkowska, E. Przebieg procesu outsourcingu usług księgowopodatkowych i jego wpływ na współprace między podmiotami [Text] / E. Marcinkowska, S. Joanna // Studia Ekonomiczne. Zeszyty Naukowe Uniwersytetu Ekonomicznego w Katowicac. 2015. - No. 225. - P. 170-180.

5. Sobańska, I. Granice organizacyjne systemu rachunkowości [Text] / I. Sobańska // Zeszyty Teoretyczne Rachunkowości. 2011. - No. 188. - P. 251-263.

6. Cebrowskiej, T. Rachunkowość wczoraj, dziś, jutro [Text] / ed. by T. Cebrowskiej, A. Kowalik, R. Stępień. - Warszawa: SKWP, 2007. - 593 p.

7. Aman, A. Transaction costs in finance and accounting offshore outsourcing: a case of Malaysia [Text] / A. Aman, N. Hamzah, R. Amiruddin, R. Maelah // Strategic Outsourcing: An International Journal. - 2012. - Vol. 5, No. 1. - P. 72-88. doi:10.1108/17538291211221960

8. Stojanov, M. The Challenges of Offshoring and Outsourcing [Electronic resource] / M. Stojanov // Trakia Journal of Sciences. 2017. - Vol. 15, Suppl. 1. - P. 87-92. - Available at: \www/ URL: http://tru.uni-sz.bg/tsj/TJS_Suppl.1_Vol.15_2017/16.pdf

9. Innowacyjna rola outsourcingu rachunkowości [Electronic resource]. - Available at: \www/URL: https://www.skwp.poznan. $\mathrm{pl} /$ files/pliki/4ea7f0030cdf5.pdf

10. Czubakowskiej, K. Od auditingu do sponsoringu w rachunkowości [Text] / ed. by K. Czubakowskiej. - Warszawa: Polskie Wydawnictwo Ekonomiczne, 2007. - 268 p.

11. Swietla, K. Outsourcing of Accounting Services as a Mechanism to Encourage the Development of Small and Mediumsized Enterprises in the Modern Economy [Electronic resource] K. Swietla // Proceedings of the 10th Conference of ASECU «TOWARDS POST-CRISIS PROSPERITY: Alternative Economic Policies and Institutional Reforms in Southern and Eastern Europe», Cluj-Napoca, Romania, 16-17 May 2014. - Cluj-Napoca: RISOPRINT, 2014. - P. 327-337. - Available at: \www/URL: http://www.asecu.gr/files/10th conf files/swietla.pdf

12. Matejun, M. Rodzaje outsourcingu i kierunki jego wykorzystania [Text] / M. Matejun // Zeszyty Naukowe Politechniki Łódzkiej. Seria: Organizacja i Zarzadzanie. - 2006. - Vol. 42, No. 989. P. 19-36.

13. Pankov, V. V. Autsorsing $\mathrm{v}$ buhgalterskom uchete [Electronic resource] / V. V. Pankov, S. A. Naumova // Audit i finansovyi analiz. - 2009. - No. 1. - Available at: \www/URL: http:// www.auditfin.com/fin/2009/1/Naumova\%20.pdf

14. Sultangujieva, A. J. Organizatsiia buhgalterskogo ucheta na usloviiah distantsionnogo autsorsinga [Electronic resource]: PhD thesis / A. J. Sultangujieva. - Moscow, 2015. - 222 p. Available at: \www/URL: https://guu.ru/files/dissertations/ 2015/06/sultanguzhieva_a_zh/dissertation.pdf

15. Maelah, R. Accounting outsourcing turnback: process and issues [Text] / R. Maelah, A. Aman, N. Hamzah, R. Amiruddin, Sofiah // Strategic Outsourcing: An International Journal. - 2010. Vol. 3, No. 3. - P. 226-245. doi:10.1108/17538291011093811

16. Swietla, K. Outsourcing usług księgowych w świetle oczekiwań biur rachunkowych i ich klientów [Text] / K. Swietla. - Krakow: Wydawnictwo Uniwersytetu Ekonomicznego w Krakowie, 2014. - 280 p.

17. Micherda, B. Ewolucja prawnych rozwiązań współczesnej rachunkowości [Text] / B. Micherda, L. Gorka. - Warszawa: Wydawnictwo C. H. Beck, 2009. - 256 p.

18. Anikin, B. A. Autsorsing: sozdanie vysokoeffektivnyh i konkurentosposobnyh organizatsii [Text] / ed. by B. A. Anikin. - Moscow: INFRA-M, 2003. - 187 p.

19. Kaledzhian, S. O. Autsorsing i delegirovanie polnomochii v deiatel'nosti kompanii [Text] / S. O. Kaledzhian. - Moscow: Delo, 2003. - 272 p.

20. Kesarchuk, H. S. Bukhhalterskyi autsorsynh: poniattia, vydy, perevahy ta nedoliky [Text] / H. S. Kesarchuk // Naukovyi visnyk Uzhhorodskoho universytetu. Seriia: Ekonomika. - 2014. Vol. 1 (42). - P. 201-204.

21. Popliuiko, A. M. Bukhhalterskyi autsorsynh: suchasnyi stan ta perspektyvy rozvytku v Ukraini [Text] / A. M. Popliuiko // Finansy, oblik i audyt. - 2011. - Vol. 18. - P. 335-340.

22. Liakhovych, H. I. Bukhhalterskyi autsorsynh: pidkhody do traktuvannia ta klasyfikatsii [Text] / H. I. Liakhovych // Naukovyi visnyk Uzhhorodskoho natsionalnoho universytetu. Seriia: Mizhnarodni ekonomichni vidnosyny ta svitove hospodarstvo. 2016. - Vol. 9. - P. 104-108. 


\section{КЛАССИФИКАЦИЯ БУХГАЛТЕРСКОГО АУТСОРСИНГА:} СООТВЕТСТВИЕ СОВРЕМЕННЫМ ТЕНДЕНЦИЯМ РАЗВИТИЯ

Проведен анализ существующих на сегодняшний день классификаций бухгалтерского аутсорсинга. Сделана оценка определенных учеными классификационных признаков на соответствие потребностям в обеспечении эффективности бухгалтерского аутсорсинга. Предложено осуществлять его классификацию по следующим признакам, представленных в трех группах: в зависимости от предоставляемых услуг; в зависимости от субъектов хозяйствования и в зависимости от требований к организации аутсорсинга.

Ключевые слова: бухгалтерский аутсорсинг, организация бухгалтерского учета, классификация бухгалтерского аутсорсинга.

Liakhovych Halyna, PhD, Associate Professor Director IvanoFrankivsk Institute of Management Studies of the Ternopil National Economic University, Ukraine, e-mail: kaffinance@ukr.net, ORCID: https://orcid.org/0000-0002-0077-9128

\section{Mykolaichuk I., Sylkina Y., Sychova $\mathbf{N}$.}

\section{INVESTIGATION OF SOCIALLY RESPONSIBLE BEHAVIOR OF TRADE ENTERPRISES ON A COMPETENT- BASED APPROACH}

Досліджено сутність та значення сочіальної відповідальності підприємства як наукової концепиії. Визначено складові соціальної відповідальності підприємства. Розглянуто особливості становлення соціально-відповідальної поведінки підприємств торгівлі на сучасному етапі їх функиіонування. Виконано аналіз сутності компетентного підходу як методу наукового-практичного аналізу соціально-економічної системи в чілому, так методу впливу на індивідуальну поведінку підприємства торгівлі, зокрема.

Ключові слова: сочіальна відповідальність, сочіально-відповідальна поведінка підприємства торгівлі, компетентнісний підхід, компетенції підприємства.

\section{Introduction}

Globalization challenges, the main cause of which is the general decline in the volume of national production and the crisis phenomena in all spheres of economic activity, negatively affected the state of Ukraine's domestic trade, has recently undergone significant changes under the influence of crisis phenomena. Despite the difficult economic and political situation, trade is characterized by a slight decline in performance indicators compared to other spheres of economic activity. Due to significant political and economic transformations, the country's demand for goods and services is declining. In turn, this leads to a decrease in the profits of trade enterprises, causes an imbalance in the demand and supply of the consumer market, caused by the mismatch of social production and the unstable development of trade and intermediary activities. At the same time, the principles of responsible behavior become a significant competitive advantage of their activity and increase of business reputation in the region, taking into account the social orientation and significance for the consumers of the enterprise and for each employee as much as possible. Their definition is based on various scientific approaches and assessment methods, one of which is the competence approach, is spreading in connection with the need to develop the skills of managers to successfully solve operational and strategic socially significant tasks for the survival and competitiveness of enterprises. Taking this into account, research on the socially responsible behavior of trade enterprises is an urgent problem, determines the formation and development of their specific advantages in the Ukrainian business environment.

\section{The object of research and its technological audit}

The object of research is the problems of the formation of social behavior of trade enterprises at the present stage of their functioning and development. Increasing the level of competitiveness of trade enterprises is determined by many factors, including their accumulated potential, the basis of which is the formation of organizational competencies. The practice of the functioning of trade enterprises testifies to existing problems in the stability of contractual relations with business partners, in increasing current operating costs, capitalization of enterprises, changes in the qualitative and quantitative composition of personnel, dissatisfaction of workers in the system of motivation and working conditions, and the like.

In this regard, increasing the level of competitive advantage to enterprises along with other methods can ensure compliance with the principles of social responsibility to the society, consumers and workers themselves. One of the most problematic areas in the outlined problems of the study is the use of a competence approach to the formation of socially responsible behavior of trade enterprises, based on the principles of identifying the most significant socially-oriented activities of competition and survival in the market. 